\title{
Bottom-up or Top-down Reading Strategies: Reading Strategies Used by EFL Students
}

\author{
Bintang Nadea A. B. ${ }^{*}$, Jumariati ${ }^{2}$, Nasrullah ${ }^{3}$ \\ 1,2,3 Lambung Mangkurat Univeristy \\ "Corresponding author. Email: $1710117320009 @ m h s . u l m . a c . i d ~$
}

\begin{abstract}
To strengthen the understanding of reading, a reader needs to apply a certain strategy. Although previous research on reading strategies has been carried out, little research has been devoted to investigating reading strategies involving EFL learners. The main objective of this study was to investigate the students' reading strategies of the English Language Education Study Program of FKIP ULM. It applied a descriptive quantitative approach involving 60 students. The data was collected by using a questionnaire and interview guidelines. The findings showed that students employed bottom-up and top-down strategies, such as reading the title to determine the text's main idea, reading the first paragraph, concentrating on the first and last sentences, reading the passage quickly, reading the difficult part aloud, focusing on the first sentence, guessing the meaning, and taking notes. These findings suggest that more exercises are needed to develop reading strategies to help students achieve the reading target more effectively.
\end{abstract}

Keywords: Bottom-up, Reading, Reading strategies, Top-down

\section{INTRODUCTION}

English is the main international language taught in Indonesian schools. School graduates are expected to be able to compete on an international level, which demands English fluency in four language skills: listening, speaking, reading, and writing. Regarding reading skills, many Indonesian students are still not aware of the benefits of having good reading habits, let alone reading in English as a foreign language.

Reading in foreign language contexts has always remained an important issue [1]. In terms of reading skills, Grabe and Stoller [1] defined reading as "the ability to draw meaning from the printed page and interpret this information appropriately". It is influenced by three factors: the text, the reader, and the reading situation. They read as beginning with identifying the smallest units of language, i.e., letters, which are followed by the next level (words) that are joined together to make sentences, which in turn make paragraphs. English language learners who use at least two languages for processing struggle with developing English reading comprehension skills. They have culturally different schemata and limited English vocabulary knowledge [2].

Readers use a variety of reading strategies, including identifying a reading goal, making a plan for what to accomplish or what steps to take, previewing the text, trying to predict the contents of the text or a component of the text, posing questions about the topic, searching for answers to posed specific questions, linking text to previous knowledge, summarizing details, rereading, guessing the meaning of a particular word from context, using language forms to see the relationship, connecting parts of the text, paying much attention to language structures, criticizing the author, critiquing the text, establishing how well the explanations for reading were met, giving an opinion on what was learned from the text, and drawing inferences. [3].

Reading ability is measured at all levels of the educational system, including university students in Indonesia. The standard of competence and basic competencies of English reading skills for university students that must be achieved is to understand academic literacy. However, there are several main 
problems faced by students in reading comprehension. The students still have difficulty finding the general idea of a text, identifying the meaning of words, and finding main ideas.

To overcome the problems above, there are two kinds of reading strategies. The first is bottom-up; it focuses on the development of basic skills, matching sounds with letters, syllables, and words used in writing the text. The second strategy is top-down, which is based on the reader's prior knowledge to comprehend a written text. Reading activities of the bottom-up strategy starts from a basic introduction to writing and sounding out words to recognize the grapheme, morpheme, and word, and identify grammatical structures, sentences, and text. In a top-down strategy, the reading activities begin with forecasting from the title of the reading text that permits them to restrict the scope of their reading.

Studies have been carried out to investigate reading strategies applied by EFL learners. The results show that EFL learners are aware of almost all effective reading strategies, though each one is not used individually [4]. Another study found that EFL learners used global strategies, problem-solving strategies, and support strategies [5]. Hence, the purpose of this study is to look into the reading strategies utilized by FKIP ULM batch 2019 ELESP students, primarily top-down and bottomup reading strategies.

\section{LITERATURE REVIEW}

Reading is one of the important academic skills needed by students as a source of knowledge and gratification. Reading can be described as a process of decoding, interpreting, and comprehending written information. It's a thorough procedure. It implies perceiving and identifying letters, words, spelling patterns, and major linguistic units in a precise, sequential manner [6]. Reading is a guessing game in psycholinguistics. It entails the interaction between thinking and words.

There are at least five main purposes for comprehensive reading [7]. All these purposes require the necessary skills to be accomplished efficiently. These purposes include:

- $\quad$ Reading for Specific Information

- $\quad$ Application Reading

- $\quad$ Reading for Pleasure and Entertainment

- $\quad$ Reading for Ideas

- $\quad$ Reading for Understanding

- $\quad$ Reading for Information

- $\quad$ Reading for General Main Points

- $\quad$ Selected Main Points Reading
Reading strategies are planned, goal-oriented acts that help readers comprehend and develop the meaning of a text. Reading strategies are "mental processes that readers consciously choose to use in accomplishing reading tasks" [8]. Reading strategies are cognitive games in which readers engage in a variety of interactions with textual content. This includes planning, deciding the purpose, and selecting what to read before reading [9]. Reading strategies are heuristic techniques or procedures that readers use to process and comprehend information offered in a text.

The importance of reading strategies in developing learners' reading proficiency has been supported by various empirical research, which will be discussed later in this paper. Talking about reading strategies, Hall [10] argued "it is sometimes difficult to distinguish a learning strategy from 'an immediate coping technique', and strategies can also be applied automatically even though they are commonly conceptualized as conscious actions." As a result, a strategic reader should be adaptive to a variety of reading situations and be able to choose the best strategy for each situation to enhance comprehension.

Many reading strategies can be used by the readers' activity of reading. The strategies will help them comprehend the text. Rice [11] supports this statement by giving a number of pre-reading, reading, and postreading tactics that a reader might use. Setting reading goals, thinking about what is already known about the topic, and studying the structure of a text are all strategies he recommends before starting to read. Activating prior knowledge, creating connections between essential ideas, overcoming comprehension challenges, drawing notes in the margins, or underlining major points of the material are all examples of whilereading strategies. Re-reading significant points, skimming the material, or summarizing the passage are all examples of post-reading strategies.

Additionally, effective readers employ strategies to comprehend what they read before, during, and after reading [12].

Before reading, they:

- Use prior knowledge to think about the topics.

- Make predictions about the probable meaning of the text.

- Preview the text by skimming and scanning to get a sense of the overall meaning.

During reading, they:

- Identifying what is important. 
- Monitor understanding by questioning, thinking about, and reflecting on the ideas and information in the text.

- Anticipating what is to come next.

After reading, they:

- Reflect upon the ideas and information in the text.

- Make connections between what they've read and their own experiences and expertise.

- Clarify their understanding of the text.

- Extend their understanding in critical and creative ways.

Many reading specialists have summarized reading strategies into three categories: bottom-up, top-down, and interactive models [13].

\section{- $\quad$ Bottom-up Strategies}

This strategy is described as a procedure that incorporates perceptual accuracy, sound, and the ability to discover a series of texts, words, spelling patterns, and other language units. Readers attempt to comprehend the text by constructing meaning from the smallest to the greatest components.

Bottom-up reading does not address the entire reading process for proper understanding [14]. Bottomup reading is the strategy to interpret letters, sounds, words, and structures until the entire text is decoded to comprehend the meaning of the text, and it is often used in the lower-level reading process. This might explain why vocalized and sub vocalized reading skills acquired by a significant amount of students.

According to the explanation above, bottom-up reading strategies involve analyzing the linguistics units. Readers attempt to comprehend the text by building textual meaning from the smallest to the greatest units, then changing prior information and making predictions.

\section{- Top-down Strategies}

Top-down reading strategy is characterized as a reading procedure or psycholinguistics guessing game. Top-down reading strategies emphasize the importance of schemata, or prior experiences and background knowledge, in understanding a literary work. In topdown reading strategies, the reader must have knowledge, comprehension, and language skills that play a major role in interpreting the meaning of the text [15].

In the top-down strategy, reading can be learned by processing greater units of language focusing on the reader's knowledge. Thus, a reader integrates his knowledge into the reading. Distinctive from bottom-up, this strategy makes a reader produce meaning from a text.

\section{- Interactive model}

In the interactive model, according to Babashamsi, Bolandifar and Shakib [16], the reader engages with the text to expand its meaning, and he or she combines many types of knowledge, including linguistic or common knowledge (as a result of bottom-up processing) and schematic knowledge (through topdown processing). Compared to strictly top-down or bottom-up reading strategies, interactive reading models appear to provide a more accurate conception of reading success. Interactive models provide a better estimate of the existing information on the use of orthographic, linguistic, syntactic, semantic knowledge, and conceptual frameworks when combined with an assumption of compensatory processing, which assumes that a deficit in any specific process will result in a significant reliance on other sources of knowledge, regardless of their level in the processing hierarchy [17].

Some research has been conducted focusing on reading strategy. The study [18] explored the use of English as a Foreign Language (EFL) reading strategies used by high school students. The results of the research indicated a high awareness of reading strategy use among EFL high school students. Global reading strategies were picked by students, followed by problem-solving strategies and support strategies. Female students were more likely than male students to employ EFL reading strategies. The effects of employing EFL reading skills were also mentioned.

This research concentrates on bottom-up and top-down strategies of second language reading strategies in ELESP students at FKIP Lambung Mangkurat University in Banjarmasin, with an eye to the previous research representing preferred reading strategies in reading comprehension.

\section{METHOD}

This research used a descriptive quantitative approach to identify the most preferred reading strategies students apply when reading English texts. The subjects of the research were 60 students of ELESP FKIP ULM selected by using the purposive sampling technique. To collect the data, questionnaires and interview guidelines were utilized. 
The Survey of Reading Strategies (SORS) was used to measure the frequency of reading strategies that EFL learners applied while reading English texts. Meanwhile, the Reading Strategies Questionnaire (RSQ) was used to assess two main types of reading strategies: top-down and bottom-up. Both questionnaires were of the closedended type.

In analyzing the data, descriptive statistics were used to rank order the preferred reading strategies used by students. Finally, an interview was carried out to explore the detailed data of what reading strategies they used and strengthen the data from the questionnaires.

The key for interpreting students' responses in the questionnaires is presented in Table 1 .

Table 1. Key to Measure the Use of Reading Strategies

\begin{tabular}{c|c}
\hline $\begin{array}{c}\text { Mean } \\
\text { Score }\end{array}$ & Level of Reading Strategies Use \\
\hline $1.0-1.9$ & Very low use \\
\hline $2.0-2,4$ & Low use \\
\hline $2.5-3,4$ & Medium use \\
\hline $3.5-3.9$ & High use \\
\hline $4.0-5.0$ & Very High use \\
\hline
\end{tabular}

\section{RESULT AND DISCUSSION}

\subsection{Students Reading Strategies while Reading English Text}

The first section of the questionnaire was used to measure the frequency of reading strategies that EFL learners applied while reading English texts. The following statistics below were computed for this section:

Table 2. The Descriptive Statistics of Survey of Reading Strategies by Means

\begin{tabular}{c|l|l|l|l}
\hline No & \multicolumn{1}{|c|}{ Item Description } & $\mathrm{N}$ & Mean & SD \\
\hline 1 & $\begin{array}{l}\text { I read too slowly for } \\
\text { my educational } \\
\text { purposes when the } \\
\text { text becomes difficult. }\end{array}$ & 60 & 4.4667 & 0.74712 \\
\hline 2 & $\begin{array}{l}\text { While I'm reading, I } \\
\text { imagine the meaning } \\
\text { of unknown words or } \\
\text { phrases. }\end{array}$ & 60 & 4.3667 & 0.75838 \\
\hline 3 & $\begin{array}{l}\text { When I read, I make } \\
\text { some assumptions } \\
\text { about the meaning of } \\
\text { unfamiliar words or } \\
\text { phrases. } 60\end{array}$ & 4.1833 & 0.81286 \\
\hline
\end{tabular}

\begin{tabular}{l|l|l|l|l}
\hline 4 & $\begin{array}{l}\text { Before reading, I do } \\
\text { predict by looking at } \\
\text { the title. }\end{array}$ & 60 & 4.1833 & 0.74769 \\
\hline
\end{tabular}

As the data exhibits, the mean score for item 1 is 4.4667 (very high use--- $M>4.0$ ) while the mean score for items 2, 3, 4 are lower but still in very high use student reading strategies. If the text is difficult to grasp, the students slow down their reading to understand the content of the text. Related to item number 1, the findings indicate that most ELESP students think when the sentences become difficult to understand, they will read them again to find the meaning of the text. Apart from reading speed, students prefer to interpret the text's contents by gazing at the headline and assuming the meaning of unfamiliar words or phrases, as mentioned in items 3 and 4

\subsection{Measurement of Bottom-up and Top-Down Reading Strategies.}

Two kinds of reading comprehension strategies were measured using the Reading Strategies Questionnaire (RSQ).

Table 3. The Descriptive Statistics of Reading Strategies (Bottom-up and Top-Down)

\begin{tabular}{|c|c|c|c|c|}
\hline No & Item Description & $\mathrm{B} / \mathrm{T}$ & Mean & $\overline{S D}$ \\
\hline 9 & $\begin{array}{l}\text { I change my } \\
\text { reading speed } \\
\text { depends on the } \\
\text { difficulty of the } \\
\text { content. }\end{array}$ & B & 4.0833 & 0.82937 \\
\hline 2 & $\begin{array}{l}\text { I utilize the title to } \\
\text { aid with content } \\
\text { prediction. }\end{array}$ & $\mathrm{T}$ & 3.9667 & 0.84305 \\
\hline 8 & $\begin{array}{l}\text { begin reading } \\
\text { from the very first } \\
\text { paragraph and } \\
\text { continue till } \\
\text { reach the last } \\
\text { paragraph. }\end{array}$ & B & 3.8667 & 0.99943 \\
\hline 13 & $\begin{array}{l}\text { If I do not } \\
\text { comprehend } \\
\text { something, such } \\
\text { as a term or } \\
\text { phrase, I assume } \\
\text { l'll have to rely on } \\
\text { textual hints. }\end{array}$ & $\mathrm{T}$ & 3.8333 & 0.84706 \\
\hline
\end{tabular}

The research found that there are two kinds of reading strategies: bottom-up and top-down reading strategies. Students' most prevalent reading strategies are bottom-up. It is related to initiated strategies to interpret the subsequent starting from the small 
component, which includes word level to sentence level. It means, most ELESP students try to understand language by looking at individual meanings of grammatical characteristics of the most basic unit of the text (words for reading).

Related to the interview result, it showed that SNO, $\mathrm{RE}$, and $\mathrm{N}$ agreed with the most chosen statement in the questionnaire. Bottom-up adjusts the reading pace depending on the text difficulty. The habit of following the line in the text with a pen or finger is a simple thing, but it turns out to be one of their characteristics. In the interview, RE said that if she does not know the specific meaning of terms in the text, she tries to figure out what they imply by looking at the context.

If they grasp the contextual meaning, SNO and $\mathrm{N}$ prefer to start reading from the very first paragraph and read to the end. SNO, RE, and $\mathrm{N}$ have the same habit of reading the difficult section aloud to trigger their knowledge about the difficult word. Both of them pay more attention to the sentence's tense and adjust their reading speed according to the text's complexity. Meanwhile, RE prefers to decide what she should pay attention to and what she should ignore when reading texts.

The result of the interview also strengthens the findings of top-down reading strategies. MA and HPL as a representative of this category agreed with the statement in the questionnaire "I use the title to help predict the contents". When MA reads a text, he creates a mental image of what the text is conveying. Hence, this strategy focuses on the level of knowledge possessed by the reader. Another characteristic is that they generally skip the words that are not understood. On the contrary, bottom-up strategies make a reader comprehends the meanings of the words in the text.

Based on the findings, the strategies that were mostly used are bottom-up followed by top-down. To be specific, the students used strategies such as reading the title to determine the text's main idea, reading the first paragraph, concentrating on the first and last sentences, reading the passage quickly, reading the difficult part aloud, focusing on the first sentence, guessing the meaning, and taking notes.

Students utilize bottom-up reading strategies in an attempt to understand the meanings of words by considering the context. Reading the difficult paragraph aloud is one aspect of bottom-up strategies. Reading aloud helped students gain confidence in their ability to pronounce new or unfamiliar words, and it also increased their ability to memorize words [19].
Moreover, the bottom-up strategy wastes more time while reading, but the students say it does not matter because online learning in the pandemic era COVID-19 makes them have more time to read the whole text.

The second set of strategies used by ELESP students are top-down reading strategies. Students which use topdown reading strategies have their aim in mind by guessing what the text's theme or substance will be about and using their prior knowledge to comprehend and overview the text [20]. The students briefly considered what they might confront in the literary texts to gain an overview of the author's ideas. Readers can use predictions, activating background knowledge, and then checking confirmation, and then checking confirmation or refutations of the predictions in topdown strategies [12].

Scanning was used by students. Scanning suggested reading slowly and carefully and picking out certain keywords or phrases [21]. Students used scanning when they found questions about specific information. In line with top-down reading strategies, marking important parts is one of the characteristics. Students who have top-down reading strategies prefer to underline important parts while they are reading English text. They used this strategy to identify important information. Scanning helped them to find the specific information more easily.

Related to the speed of reading, most students with bottom-up strategies prefer to adjust the rate of reading depending on the text's difficulty. The goal is to figure out what each word in the text means. The students are also reviewing the text's most challenging part. Beale [22] pointed out speed reading strategies as "people who know how to skim and scan are flexible readers. They read according to their purpose and get the information they need quickly without wasting time. They do not need everything that increases their reading speed. " Reading slowly can make the brain wander and it will not remember anything. Reading too fast can cause the information to be lost.

Bottom-up reading strategies result in students following the lines in the text with a pen or finger to ensure sentence structure and understanding of what each pronoun refers to. The reader tries to understand the text by relying on the visual information that is on the page [23]. The brain plays an important role in interpreting the words that come from the brain, and it makes someone read faster. They combine the word meaning to get the understanding of phrases, sentences, and paragraphs until they reach the entire meaning 
while following the lines in the text. Students claimed that those strategies helped them focus when reading text.

Guessing was used by ELESP students' batch 2019 in the reading activity. They used it in identifying vocabulary. The students guessed the meaning of vocabulary by considering the text and context. Relating the background knowledge to the textual information is also used while they are reading. Therefore, it helped them identify vocabulary. Related to the top-down strategies, contextual guessing is the most important skill used by most readers in attacking new words [24].

Talking about visualization in reading, readers tend to imagine things they are reading. When they can construct their imagination to be alive, the process of comprehending messages is ongoing. In line with the statement, Azkalia [25] stated mental imagery expects readers to develop images of the text in their minds; however, there might be a possibility that learners do not follow the instruction. Thus, instructing participants to create visual images of the text might be a potential strategy to interpret and process the message.

\section{CONCLUSION}

Based on the analysis of the findings, there were two reading strategies widely used by English Language Education Study Program students' batch 2019 in EFL reading, namely: bottom-up and top-down reading strategies. The result found that students with bottom-up reading strategies are trying to understand the meaning of words by using context. The characteristics of bottom-up reading strategies that have been found in this study are: reading the difficult section aloud, rereading the difficult part, and following the line in the text with a pen or finger. The second set of strategies used by students are top-down reading strategies. Students with top-down reading strategies emphasize previous experience and relating the background knowledge to the textual information while they are reading. Moreover, the results showed that students used scanning when they found a question about specific information. Students underline the important parts while reading an English text. In line with top-down reading strategies, marking the important parts is one of the characteristics. Although participants already have their reading strategies, they also adjust the reading strategy they use according to the situation.

\section{AUTHORS' CONTRIBUTIONS}

Author 1 contributed to the design of the study, data collection, and data analysis. Authors 2 and 3 were involved in research design, data analysis, and the writing format.

\section{ACKNOWLEDGMENTS}

The authors are very grateful for the assistance of the experts of instrument validation and the subjects of the research who were willing to participate in the study.

\section{REFERENCES}

[1] W. Grabe, F. Stoller, Teaching and Researching: Reading (2nd ed), London, Routledge, 2013.

[2] Y. Iwai, Re-envisioning reading comprehension for English language learners, in: Proceedings of The Internet TESL Journal, vol. 16, 2010, pp.16-29.

[3] W. Grabe, Reading in a second language: Moving from theory to practice, Ernst Klett Sprachen, 2009.

[4] O Akarsu, L. Harputlu, Perceptions of EFL Students toward Academic Reading, in: Proceedings of The Reading Matrix, vol. 14, 2014.

[5] K. Mokhtari, C Reichard, Assessing Students' Metacognitive Awareness of Reading Strategies, in: Proceedings of Journal of Educational Psychology, vol. 94, 2002, pp. 249-259.

[6] S. Thanuskodi, Reading habits among library and Information science students of Annamalai University: a survey, in: Proceedings of International Journal of Educational Sciences, 2011, pp. 79-83.

[7] M. Marzuki, Improving Students' Reading Comprehension Through SQ3R Technique of the First Grade Students at MAN Tolitoli, in: Proceedings of Jurnal Madako Education, vol. 3, 2020.

[8] M.R. Ahmadi, H.N. Ismail, M.K. Abdullah, The Importance of Metacognitive Reading Strategy Awareness in Reading Comprehension, in: Proceedings of English Language Teaching, vol. 6, 2013, pp. 235-44.

[9] J. Meniado, Metacognitive Reading Strategies, Motivation, and Reading Comprehension Performance of Saudi EFL Student, in: Proceedings of English Language Teaching, vol. 9, 2016, pp. 117. 
[10] G. Hall, Exploring English language teaching: Language in action. Routledge, 2017.

[11] M. Rice, Research-based reading instruction: reading comprehension skills and strategies, in: Proceedings of Florida Center for Reading Research: Making Connections, Retrieved from http://www. fcrr. org/FCRRREPORTS. 2009.

[12] N. R. Fadilah, E. Harida, S. Rambe, Reading Strategies Used by Successful Readers of English Department Students of state Institute for Islamic Studies Padangsidempuan, in: Proceedings of TAZKIR: Jurnal Penelitian Ilmu-ilmu Sosial dan Keislaman, vol. 4, 2018, pp. 263.

[13] G. A. Pourhosein, NB. Sabouri, How can students improve their reading comprehension skills, in: Proceedings of Journal of Studies in Education, Vol. 6, 2016, pp. 229-40.

[14] T. Brunfaut, G. McCray, Looking into test-takers cognitive processes whilst completing reading tasks: a mixed-method eye-tracking and stimulated recall study, 2015 .

[15] R. R. Ardhani, The Effectiveness of Bottom-up and Top-down Approaches In The Reading Comprehension Skill For Junior High School Students, in: Proceedings of JEE, Journal of English and Education, vol. 5, 2016, pp. 80-90.

[16] P. Babashamsi, S. Bolandifar, N. Shakib, Various models for reading comprehension process, in: Proceedings of International Journal of Applied Linguistics and English Literature, vol. 2. 2013, pp. 150-4.

[17] M.R. Ahmadi, A.P. Gilakjani, Theory and Practice in Language Studies, Reciprocal Teaching Strategies and Their Impact on English Reading Comprehension, vol. 2, 2012, pp. 53-60.

[18] K.T. Chen, S.C. Chen, The use of EFL reading strategies among high school students in Taiwan, in: Proceedings of The Reading Matrix: An International Online Journal, vol. 15, 2015, 156-66.

[19] P. Ninsuwan, The effectiveness of teaching English by using reading aloud technique towards EFL beginners, in Proceedings of Social and Behavioral Sciences, vol. 197, 2015, pp. 35-40.

[20] V. Yousefian, Reading strategies used by Iranian EFL learners while reading academic texts, in: Proceedings of Journal of English Language Pedagogy and Practice, vol.8, 2015, pp. 192-204.
[21] A.S. Fisher, Students' reading techniques difficulties in recount text, in: Proceedings of Journal of English and Education, vol. 4 ,2016, pp. $1-2$.

[22] A.M. Beale, Skimming and scanning: Two important strategies for speeding up your reading, 2013.

[23] T. Budiharso, Reading strategies in EFL classroom: a theoretical review, in: Proceedings of Cendekia: Jurnal Pendidikan dan Pembelajaran, vol. 8, 2014, pp. 189-204.

[24] B.M. Çetinavc1, Contextual factors in guessing word meaning from the context in a foreign language, in: Proceedings of Social and Behavioral Sciences, vol. 116, 2014, pp. 70-44.

[25] R. Azkalia, Visual imagery strategy as an effort to acquire comprehension, in: Proceedings of Jurnal Profesi Keguruan, vol. 4, 2018, pp. 135. 